\title{
Recognition of nomenclatural standing of Salmonella typhi (Approved Lists 1980), Salmonella enteritidis (Approved Lists 1980) and Salmonella typhimurium (Approved Lists 1980), and conservation of the specific epithets enteritidis and typhimurium. Request for an Opinion
}

\author{
Takayuki Ezaki, Yoshiaki Kawamura and Eiko Yabuuchi
}

\author{
Author for correspondence: Takayuki Ezaki. Tel: +8158267 2240. Fax: +81582670156. \\ e-mail: tezaki@cc.gifu-u.ac.jp
}

Department of Microbiology, Gifu University School of Medicine, 40 TsukasaTsukasamachi, Gifu 500-8705, Japan

\begin{abstract}
In 1994, the Judicial Commission of the ICSB announced that Le Minor and Popoff's Request for an Opinion in 1987 to designate Salmonella enterica sp. nov., nom. rev. as the type and only species of the genus Salmonella was denied. Thus, the current species of the genus Salmonella are Salmonella typhimurium, Salmonella enteritidis, Salmonella typhi, Salmonella choleraesuis (including six subspecies) and Salmonella bongori, with the type species, S. choleraesuis (Smith 1894) Weldin 1927 (Approved Lists 1980). Because the decision of the Judicial Commission about the request by Le Minor in 1987 was suspended for 7 years, the non-validated name ' $S$. enterica' has been used among microbiologists and has caused confusion in the nomenclature of Salmonella. In order to overcome such confusion, and because of their importance as human pathogens, we herein propose to recognize the nomenclatural status of $S$. typhi, S. enteritidis and $S$. typhimurium as species and request to issue an Opinion to conserve the specific epithets enteritidis and typhimurium in the species names Salmonella enteritidis and Salmonella typhimurium.
\end{abstract}

Keywords: Salmonella typhi, Salmonella enteritidis, Salmonella typhimurium, conserved name, taxonomy
The members of the genus Salmonella were divided into more than 2300 serovars and most of them were proved to genetically belong to a single species (Christensen et al., 1998; Crosa et al., 1973; Reeves et al., 1989a; Stoleru et al., 1976). Historically, however, classification of the genus Salmonella was exposed to extensive arguments by many microbiologists. In the 1st edition of Bergey's Manual of Determinative Bacteriology in 1923 (Bergey et al., 1923), 17 species in the genus Salmonella were described and each species was biochemically differentiated. Until the first issue of the International Bulletin of Bacteriological Nomenclature and Taxonomy in 1951, several different classification systems based on biochemical traits and antigenic structure have been proposed (Borman et al., 1944; Kauffmann, 1952). In 1948, Kauffmann described 150 'serotypes' in the 6th edition of Bergey's Manual
(Kauffmann, 1948), however, in 1952, he described only three species, which could be differentiated by biochemical tests (Kauffmann \& Edwards, 1952). In 1980, the Approved Lists of Bacterial Names (Skerman et al., 1980) cited five species in the genus Salmonella: S. typhi, S. enteritidis, S. choleraesuis, S. arizonae and S. typhimurium, among more than 2000 serovars in the genus Salmonella.

In 1982, based on the results of numerical analysis and DNA-DNA hybridization among 88 Salmonella reference strains belonging to be subgenera I-IV by Kauffman (Le Minor et al., 1982a). Le Minor et al. (Le Minor et al., 1982b) proposed to combine four Salmonella subgenus strains into a single species, namely Salmonella choleraesuis, and described six subspecies; S. choleraesuis subsp. choleraesuis, $S$. 
choleraesuis subsp. salamae, S. choleraesuis subsp. arizonae, $S$. choleraesuis subsp. diarizonae, $S$. choleraesuis subsp. houtenae, S. choleraesuis subsp. bongori. This proposal was made outside the International Journal of Systematic Bacteriology (IJSB) and the six subspecies appeared later in the Validation List no. 18 (Le Minor et al., 1985).

Through this proposal, Le Minor et al. intended to place all Salmonella serovars in the Salmonella choleraesuis subsp. choleraesuis in his original report which appeared in the journal of the Pasteur Institute (Le Minor et al., 1986; Le Minor \& Popoff, 1987). However, an official proposal to place S. typhi, S. typhimurium and $S$. enteritidis as subjective synonyms of Salmonella choleraesuis subsp. choleraesuis, did not appear in a Validation List in IJSB. So, S. typhi, $S$. typhimurium and $S$. enteritidis remained as validly named species. Only the six subspecies that he proposed were later cited in Validation List no. 18 (Le Minor et al., 1985).

The seventh subspecies, S. choleraesuis subsp. indica, was proposed by Le Minor et al. (Le Minor et al., 1986) and validly named in List no. 23 (Le Minor et al., 1987). Thus, at this stage, S. choleraesuis contained seven subspecies.

After the proposal of Le Minor et al. in 1982, Le Minor and Popoff requested an Opinion to designate Salmonella enterica sp. nov., nom. rev. as the type species of the genus Salmonella in 1987 (Le Minor \& Popoff, 1987), i.e. they proposed S. enterica as a single species in the genus Salmonella. S. typhi, S. typhimurium and $S$. enteritidis were included in the $S$. enterica. Salmonella enterica originally was used by Edwards \& Ewing (1963). Le Minor et al. designated strain LT2 as the type strain of S. enterica. This strain was the reference strain for S. typhimurium. After the submission of Le Minor and Popoff's Request for an Opinion, the Judicial Commission took 7 years to act on it and finally did not accept Le Minor and Popoff's proposal (Wayne, 1994). However, Le Minor and Popoff's proposal was widely distributed among microbiologists.

In 1989, S. choleraesuis subsp. bongori was placed as a distinct species, S. bongori (Le Minor et al. 1985) Reeves et al. 1989 (Reeves et al., 1989a, b). Thus, currently, five species and six subspecies of $S$. choleraesuis have taxonomic positions as in Table 1.

From the historical background, nomenclature of the members of the genus Salmonella has been confused in the scientific community. The species name of Salmonella typhi is still valid nomenclaturally although this species is genetically identical to $S$. choleraesuis subsp. choleraesuis because of their high DNA-DNA similarity value (Crosa et al., 1973; Stoleru et al., 1976). However, the name of this organism was well known and used from early in the last century because this organism causes severe epidemic disease, typhoid fever. The organism is also listed as a Level 3 pathogen
Table 1. Validly named species and subspecies in the genus Salmonella

\begin{tabular}{|ll|}
\hline Validly named taxa & Type strain \\
\hline Salmonella choleraesuis & ATCC 13312 \\
Salmonella choleraesuis subsp. choleraesuis & ATCC 13312 \\
Salmonella choleraesuis subsp. salamae & CIP 8229 \\
Salmonella choleraesuis subsp. arizonae & ATCC 13314 \\
Salmonella choleraesuis subsp. diarizonae & CIP 8231 \\
Salmonella choleraesuis subsp. houtenae & CIP 8232 \\
Salmonella choleraesuis subsp. indica & CIP 102501 \\
Salmonella enteritidis & ATCC 13076 \\
Salmonella typhimurium & ATCC 13311 \\
Salmonella typhi & ATCC 19430 \\
Salmonella bongori & CIP 8233
\end{tabular}

in the bacterial hazard group of the WHO and many countries. Further, the specific epithet typhi in combination with the genus name Salmonella is conserved by Opinion 18 in 1963 (Editorial Board, 1963). To clarify the position of the name $S$. typhi, we propose that the Judicial Commission act to recognize the species $S$. typhi as a legitimate name and confirm the name as nomen conservandum according to Rule 56b.

Concerning rejection of names, ICSB added a new item, (5), to Rule 56a: 'a perilous name (nomen periculosum), i.e., a name whose application is likely to lead to accidents endangering health or life or both or of serious economic consequences' (Lapage et al., 1992). The attempt to change the name of $S$. typhi to $S$. choleraesuis subsp. choleraesuis serovar typhi should be rejected according to Rule 56a.

Though strains of S. typhimurium and S. enteritidis are also genetically identical to $S$. choleraesuis subsp. choleraesuis (Christensen et al., 1998; Crosa et al., 1973; Stoleru et al., 1976), these two species name appeared in the Approved Lists and retained their nomenclatural standing. In contrast to this, $S$. choleraesuis subsp. choleraesuis serovar typhimurium, $S$. choleraesuis subsp. choleraesuis serovar enteritidis are to be rejected as nomina periculosa since the two species are now most important human and animal pathogens. They cause outbreaks of food poisoning and fatal systemic infection among children. Their names are widely recognized and appeared in the Approved Lists of Bacterial Names (Skerman et al., 1980, 1989). We propose to the Judicial Commission to act to re-recognize $S$. typhimurium and $S$. enteritidis as legitimate names and Request an Opinion to protect their specific epithets as nomina conservanda.

\section{References}

Bergey, D. H., Harrison, F. C., Breed, R. S., Hammer, B. W. \& Huntoon, F. N. (1923). Bergey's Manual of Determinative Bacteriology. Baltimore: Williams \& Wilkins.

Borman, E. K., Stuart, C. A. \& Wheeler, K. (1944). Taxonomy of the family. $J$ Bacteriol 48, 351-367. 
Christensen, H., Nordentoft, S. \& Olsen, J. E. (1998). Phylogenetic relationships of Salmonella based on rRNA sequences. Int J Syst Bacteriol 48, 605-610.

Crosa, J. H., Brenner, D. J., Ewing, W. H. \& Falkow, S. (1973). Molecular relationship among the Salmonella. J Bacteriol 115, 307-315.

Ewing, W. H. (1963). An outline of nomenclature for the family Enterobacteriaceae. Int Bull Bacteriol Nomencl Taxon 13, 95-110.

Editorial Board (for the Judicial Commission of the International Committee on Bacteriological Nomenclature) (1963). Opinion 18. Conservation of typhi in the binary combination Salmonella typhi. Int Bull Bacteriol Nomencl Taxon 13, 31-38.

Kauffmann, F. (1948). Genus 1. Salmonella Linieres. In Bergey's Manual of Determinative Bacteriology. Edited by R. S. Breed, E. G. D. Murray \& A. P. Hitchens. Baltimore: Williams \& Wilkins.

Kauffmann, F. (1961). The species definition in the Enterobacteriaceae. Int Bull Bacteriol Nomencl Taxon 11, 5-6.

Kauffmann, F. \& Edwards, P. R. (1952). Classification and nomenclature of Enterobacteriaceae. Int Bull Bacteriol Nomencl Taxon 2, 2-8.

Lapage, S. P., Sneath, P. H. A., Lessel, E. F., Skerman, V. B. D., Seeliger, H. P. R. \& Clark, W. A. (editors) (1992). International Code of Nomenclature of Bacteria (1990 Revision). Bacteriological Code. Washington, DC: American Society for Microbiology.

Le Minor, L. \& Popoff, M. Y. (1987). Request for an Opinion. Designation of Salmonella enterica sp. nov., nom. rev., as the type and only species of the genus Salmonella. Int J Syst Bacteriol 37, 465-468.

Le Minor, L., Véron, M. \& Popoff, M. Y. (1982a). Taxonomie des Salmonella. Ann Microbiol (Inst Pasteur) 133B, 223-243.

Le Minor, L., Véron, M. \& Popoff, M. Y. (1982b). Proposition pour une nomenclature des Salmonella. Ann Microbiol (Inst Pasteur) 133B, 245-254.

Le Minor, L., Véron, M. \& Popoff, M. Y. (1985). Salmonella cholerae-suis subsp. arizonae comb. nov., Salmonella choleraesuis subsp. bongori subsp. nov., Salmonella cholerae-suis subsp. cholerae-suis subsp. nov. (Smith) Weldin, Salmonella choleraesuis subsp. diarizonae subsp. nov., Salmonella cholera-suis subsp. houtenae subsp. nov., Salmonella cholera-suis subsp. salamae subsp. nov. In Validation of the Publication of New Names and New Combinations Previously Effectively Published Outside the IJSB, List no. 18. Int J Syst Bacteriol 35, 375-376.

Le Minor, L., Popoff, M. Y., Laurent, B. \& Hermant, D. (1986). Individualisation d'une septième sous-espèce de Salmonella: $S$. choleraesuis subsp. indica subsp. nov. Ann Inst Pasteur Microbiol 137B, 211-217.

Le Minor, L., Popoff, M. Y., Laurent, B. \& Hermant, D. (1987). Salmonella choleraesuis subsp. indica subsp. nov. In Validation of the Publication of New Names and New Combinations Previously Effectively Published Outside the IJSB, List no. 23. Int J Syst Bacteriol 37, 179-180.

Reeves, M. W., Evins, G. M., Heiba, A. A., Plikaytis, B. D. \& Farmer, J. J., III (1989a). Clonal nature of Salmonella typhi and its genetic relatedness to other salmonellae as shown by multilocus enzyme electrophoresis, and proposal of Salmonella bongori comb. nov. J Clin Microbiol 27, 313-320.

Reeves, M. W., Evins, G. M., Heiba, A. A., Plikaytis, B. D. \& Farmer, J. J., III (1989b). Salmonella bongori comb. nov. In Validation of the Publication of New Names and New Combinations Previously Effectively Published Outside the IJSB, List no. 30. Int J Syst Bacteriol 39, 371.

Skerman, V. B. D., McGowan, V. \& Sneath, P. H. A. (1980). Approved lists of bacterial names. Int J Syst Bacteriol 30, 225-420.

Skerman, V. B. D., McGowan, V. \& Sneath, P. H. A. (editors) (1989). Approved Lists of Bacterial Names (amended edition). Washington, DC: American Society for Microbiology.

Stoleru, G. H., Le Minor, L. \& Lheritier, M. (1976). Polynucleotide sequence divergence among strains of Salmonella subgroup IV and closely related organisms. Ann Microbiol (Paris) 127A, 447-486.

Wayne, L. G. (1994). Actions of the Judicial Commission of the International Committee on Systematic Bacteriology on Requests for Opinions published between January 1985 and July 1993. Int J Syst Bacteriol 44, 177-178. 